\title{
PENGUMPULAN DATA PRODUKTIVITAS TANAMAN PANGAN PADA MASA PANDEMI COVID-19
}

\author{
The Data Collection of Food Crop Productivity In The Covid-19 Pandemic Period
}

\author{
Nialita Rahmadhani ${ }^{1}$ \\ Badan Pusat Statistik ${ }^{1}$ \\ Jl. DR. Sutomo No. 6-8 Jakarta 10710 \\ E-mail: nialita@bps.go.id
}

\begin{abstract}
ABSTRAK
Mewabahnya Covid-19 telah menimbulkan dampak yang tidak hanya pada dunia kesehatan, namun sektor-sektor lain termasuk sektor pangan dan pertanian juga mendapat pengaruh dari adanya virus tersebut. Dengan adanya peringatan dari Organisasi Pangan dan Pertanian (FAO) mengenai potensi kelangkaan pangan dunia, presiden Joko Widodo menginstruksikan untuk memastikan ketersediaan bahan pokok secara akurat berdasar pada data-data yang valid. Hal ini menjadi tantangan bagi BPS untuk melakukan penyesuain metodologi supaya tetap bisa memenuhi kebutuhan data pangan, salah satunya melalui survei ubinan. Tujuan dari penelitian ini menjelaskan mitigasi dan adaptasi metodologi pelaksanaan survei ubinan, serta menyampaikan evaluasi dampak perubahan tersebut. Data yang digunakan adalah Data Ubinan Subround 1 2019 dan subround 12020 yang dikumpulkan oleh BPS. Metode analisis yang digunakan adalah analisis deskriptif dan analisis paired samples $t$-test. Hasil penelitian menunjukkan bahwa pemasukan data (response rate) komoditas padi pada subround 12020 hanya mencapai 65,10\%, sebanyak 70,49\% petugas tetap menggunakan metode pengukuran dan wawancara, dan tidak ada perbedaan hasil ubinan sebelum pandemi Covid-19 (Subround I 2019) dengan saat pandemi Covid-19 (Subround 1 2020). Dengan demikian, dapat disimpulkan bahwa Metode wawancara tanpa pengukuran bisa menjadi alternatif karena tidak ada perbedaan yang cukup signifikan antara produktivitas padi metode pengukuran dan wawancara dengan metode wawancara tanpa pengukuran.
\end{abstract}

Kata kunci: produktivitas, Covid-19, wawancara, padi

\section{ABSTRACT}

The Covid-19 has had an impact not only on the world of health, but also other sectors including the food and agriculture sectors. Food and Agriculture Organization (FAO) regarding the potential of world food scarcity, president Joko Widodo instructed to ensure the availibility of food accurately based on valid data. This is a challenge for BPS to make methodological adjustments so that it can still provide food data, which is crop cutting survey. The purpose of this study is to explain the mitigation and adaptation of the methodology of crop cutting survey, and to provide an evaluation of the impact of these changes. Data used were the subround 12019 and Subround 12020 of crop cutting survvey collected by BPS and then analyzed using the descriptive method and further analyzed using paired samples t-test analysis. The results showed that the data entry (response rate) for paddy commodities in subround 12020 only reached 65,10\%, as many as $70,49 \%$ of officers still used the measurement and interview method and ther was no difference inthe results of crop cutting survey before the covid-19 pandemic (Subround 1 2019) with the time covid-19 pandemic (subround 12020). So it can be concluded that the interview method without measurement can be an alternative because there is no significant difference between the paddy productivity of the measurement method and interviews with the interview without measurement.

Keywords: productivity, Covid-19, interview, paddy

\section{PENDAHULUAN}

Sejak awal Maret 2020, virus corona atau dikenal dengan Covid-19 mulai merebak di Tanah Air. Penyebaran wabah pandemi Covid-19 yang sangat cepat bukan hanya berdampak luas di dunia kesehatan, namun sektor-sektor lain juga mendapat pengaruh dari adanya virus tersebut. Kondisi ini telah menekan pertumbuhan ekonomi global dan menimbulkan dampak sosial dan ekonomi yang semakin meluas, termasuk di sektor pangan dan pertanian (Hermanto et al., 2020). Meskipun gangguan terhadap produksi pangan dan pertanian belum terlihat nyata ditingkat lapangan, namun Organisasi Pangan dan Pertanian (FAO) dalam situs resminya tanggal 30 Maret 2020, mengingatkan 
akan adanya potensi kelangkaan pangan dunia (FAO, 2020). Menyikapi peringatan ini, Presiden Joko Widodo dalam rapat terbatas melalui konferensi virtual bersama wakil presiden Ma'ruf Amin dan para menteri kabinet indonesia maju menginstruksikan untuk memastikan ketersediaan bahan pokok dan produksi beras dikalkulasi dengan cermat dan dihitung dengan lengkap berbasis data empiris yang valid dan reliabel (Sekretariat Kabinet RI, 2020).

Untuk mencegah mata rantai penyebaran Covid-19, beberapa instansi pemerintah termasuk Badan Pusat Statistik mengeluarkan kebijakan untuk menjaga physical distancing(menjaga jarak antar manusia dengan menghindari kerumunan) dalam bekerja berdasarkan Surat Edaran Menteri Pendayagunaan Aparatur Negara dan Reformasi Birokrasi Nomor 19 Tahun 2020 tentang penyesuaian sistem kerja aparatur sipil negara dalam upaya pencegahan penyebaran Covid-19 di lingkungan instansi pemerintah (Menpan RB, 2020). Hal ini merupakan tantangan bagi BPS sebagai sumber data terpercaya untuk memenuhi kebutuhan data pangan yang menjadi dasar pengambilan keputusan pada masa pandemi Covid-19.

Salah satu informasi penting yang dibutuhkan dalam menghitung produksi tanaman pangan adalah hasil per hektar (produktivitas). Data produktivitas dikumpulkan melalui survei ubinan yang berbasis rumah tangga untuk tanaman palawija dan berbasis kerangka sampel area untuk tanaman padi. Institut Pertanian Bogor telah melakukan pengujian untuk mengevaluasi penghitungan produksi padi di Indonesia yang hasilnya bahwa data produktivitas dari survei ubinan dapat dipercaya walaupun terdapat bias dalam pelaksanaanya (Hidayat et al., 2018). Survei ubinan rutin dilakukan setiap tahun dalam tiga periode, yaitu Subround/SR I (periode Januari-April), SR II (periode Mei-Agustus), dan SR III (periode September-Desember). Unit observasi dalam pelaksanaan survei ubinan adalah plot area tanaman pangan siap panen yang diusahakan oleh rumah tangga sampel berukuran $2,5 \mathrm{~m} \times 2,5 \mathrm{~m}$ yang dipilih secara acak. Pengumpulan data produktivitas tanaman pangan menerapkan metode pengukuran langsung pada plot ubinan terpilih dan metode wawancara dengan petani sampel untuk mengumpulkan data beberapa karakteristik yang berkaitan dengan produktivitas seperti penggunaan pupuk, benih, pestisida, cara penanaman, dan sebagainya (BPS, 2015). Namun, kedua tahapan ini tidak bisa sepenuhnya dilakukan pada masa pandemi covid-19, perlu adanya penyesuaian karena ada beberapa daerah yang menerapkan Pembatasan Sosial Bersakala Besar (PSBB) dan lockdown (Mahardika et al., 2020). Krisis situasi membutuhkan pendekatan yang fleksibel, tetapi pada saat yang sama bisa berdampak minimal pada kualitas (Bidarbakhtnia et al., 2020).

Tujuan dari penelitian ini menjelaskan mitigasi dan adaptasi metodologi pelaksanaan survei ubinan, serta menyampaikan evaluasi dampak perubahan tersebut yang diukur melalui deskripsi Response Rate survei ubinan pada masa pandemi Covid-19, menggambarkan proporsi metode yang digunakan untuk pelaksanaan survei ubinan pada masa pandemi Covid-19, dan mengetahui perbedaan produktivitas berdasarkan metode pelaksanaan yang disesuaikan dengan masa pandemi Covid-19.

\section{METODE}

Data yang digunakan dalam penelitian ini adalah data primer dari raw data (data mentah) hasil survei ubinan Subround I (periode Januari-April) tahun 2019 dan 2020 komoditas padi. Pengumpulan data produktivitas padi dengan survei ubinan menerapkan metode pengukuran langsung pada plot terpilih. Pelaksanaan ubinan dilakukan bersama oleh BPS dan Dinas Pertanian Kabupaten/Kota. Pemilihan plot ubinan dilakukan secara acak. Setelah plot ubinan dipanen, timbang hasil panen dengan timbangan dan hasilnya dalam bentuk Gabah Kering Panen (GKP) yang dikonversi menjadi Gabah Kering Giling (GKG).

Namun akibat dari pandemi Covid-19, pada Subround I 2020 ditetapkan alternatif metode pengumpulan data yang disesuaikan dengan kondisi masing-masing wilayah yaitu pengumpulan data dilakukan dengan metode pengukuran dan metode wawancara tanpa pengukuran. Kualitas data dengan metode wawancara tanpa pengukuran bergantung pada kejujuran jawaban dan ingatan responden karena nilai statistik yang diperoleh bersifat pengakuan. Untuk mendapatkan data produktivitas padi metode wawancara tanpa pengukuran digunakan persamaan berikut:

$$
y_{i}=\frac{0,8602\left(x_{i}\right)}{z_{i}} \times \frac{10.000 \mathrm{~m}^{2}}{1.000 \mathrm{~kg}}
$$


dimana:

$\mathrm{y}_{\mathrm{i}}=$ produktivitas padi (ton/ha) pada responden ke- $i$ hasil wawancara

0,8602 = nilai konversi dari Gabah Kering Panen (GKP) ke Gabah Kering Giling (GKG)

$\mathrm{X}_{\mathrm{i}}=$ produksi padi $(\mathrm{kg})$ pada responden ke- $i$ dalam bentuk GKP yang diperoleh dari hasil wawancara

$\mathrm{z}_{\mathrm{i}}=$ luas panen $\left(\mathrm{m}^{2}\right)$ pada responden ke- $i$ yang diperoleh dari hasil wawancara

Variabel yang akan diperbandingkan adalah produktivitas padi survei ubinan subround I 2020

berdasarkan pengukuran dan wawancara tanpa pengukuran dengan menggunakan paired samples

t-testdan korelasi pearson.Unit observasi dalam penelitian ini adalah seluruh provinsi di Indonesia yang terdiri dari 34 provinsi, dikelompokkan menjadi lima pulau, yaitu:

- Sumatera : Aceh, Sumatera Utara, Sumatera Barat, Riau, Jambi, Sumatera Selatan, Bengkulu, Lampung, Kepulauan Bangka Belitung, dan Kepulauan Riau.

- Jabaltera : DKI Jakarta, Jawa Barat, Jawa Tengah, DI Yogyakarta, Jawa Timur, Banten, Bali, Nusa Tenggara Barat, dan Nusa Tenggara Timur.

- Kalimantan : Kalimantan Barat, Kalimantan Tengah, Kalimatan Selatan, Kalimantan Timur, dan Kalimantan Utara.

- Sulawesi : Sulawesi Utara, Sulawesi Tengah, Sulawesi Selatan, Sulawesi Tenggara, Gorontalo, dan Sulawesi Barat.

- Maluku Papua : Maluku, Maluku Utara, Papua Barat, dan Papua.

\section{Paired Samples T-Test}

Teknik statistik paired samples $t$-test membandingkan obyek yang sama namun mendapat perlakuan yang berbeda. Teknik ini dipilih dengan alasan setiap pulau dianggap sebagai obyek yang diberi perlakuan yang berbeda. Masing-masing pulau diberi dua perlakuan. Perlakuan pertama adalah dengan metode pengukuran lapangan dan perlakuan kedua adalah metode wawancara tanpa pengukuran. Tahapan pengujian paired samples $t$-test adalah:

1. Menentukan hipotesis penelitian:

$\mathrm{H}_{0}$ : tidak terdapat perbedaan yang signifikan antara produktivitas padi hasil wawancara dan hasil pengukuran.

$\mathrm{H}_{1}$ : ada perbedaan yang signifikan antara produktivitas padi hasil wawancara dan hasil pengukuran.

2. Peluang tolak $\mathrm{H}_{0}$ padahal $\mathrm{H}_{0}$ benar (taraf nyata) sebesar a. Dalam penelitian ini ditentukan $a=5 \%$.

3. Statistik uji :

$$
t^{*}=\frac{\bar{y}_{d}-\mu_{0}}{S_{d} / \sqrt{n}}
$$

Dimana:

$\mathrm{d}=$ selisih $\mathrm{y}_{1}$ dan $\mathrm{y}_{2}$

$\mathrm{n}=$ jumlah sampel

$\bar{y}=$ rata-rata

$\mathrm{S}_{\mathrm{d}}=$ Standar Deviasi dari $\mathrm{d}$

4. Uji Signifikansi dengan kaidah : tolak $\mathrm{H}_{0}$ jika $\mid t$ hitung $\mid>t$ tabel

Statistik uji Paired samples t-test mengikuti distribusi student-t dan dapat diterapkan untuk $\mathrm{n}$ berukuran kecil ((Lind, Douglas A., Marchal, William G., Wathen, 2012)

\section{HASIL DAN PEMBAHASAN}

Agar kebutuhan data pangan yang valid dan akurat tetap terpenuhi di masa pandemi Covid-19 ini, BPS mengambil langkah strategis dan kebijakan pada pelaksanaan kegiatan statistik tanaman pangan khususnya pengumpulan data produktivitas komoditas padi dalam survei ubinan. Berikut skenario antisipasi pelaksanaan survei ubinan selama masa Covid-19 yang dibandingkan dengan pelaksanaan pada kondisi normal: 
Tabel 1. Skenario pelaksanaan survei ubinan pada kondisi normal dan kondisi pandemi Covid-19. Kondisi Normal Kondisi Pandemi Covid-19

Metodolog Padi : sampel subsegmen dipilih di BPS Pusat.

Palawija : Sampel rumah tangga dipilih di BPS Kab/Kota melalui proses listing blok sensus sebelumnya.

Pemilihan sampel rumah tangga baik untuk padi maupun palawija, dilakukan oleh direktorat Pengembangan Metodologi Sensus dan Survei, BPS, yang berasal dari rumah tangga terpilih tahun 2019 dan/atau subround 12020 yang dilengkapi dengan nomor telepon.

Instrumen Kuesioner lengkap SUB-S Kuesioner sederhana SUB-SW, rincian yang Data produktivitas didapat dari ditanyakan pada kuesioner ini hanya pendekatan plot sampel yang diubin. identitas sampel, bulan panen, jenis lahan, varietas, luas panen, berat hasil panen, dampak serangan OPT, dampak fenomena iklim, perbandingan produktivitas Subround yang sama pada tahun lalu dan identitas petugas.

Data produktivitas didekati dengan produktivitas bidang/petak.

Pelaksanaan Pengumpulan data dilakukan dengan lapangan pengukuran dan wawancara. Pengumpulan data bisa dilakukan dengan wawancara tanpa pengukuran, disesuaikan dengan kondisi daerah masing-masing.

\section{Sumber: BPS}

Skenario pengumpulan data dilakukan dengan wawancara sejalan dengan metode pengumpulan data produksi pada banyak survei dan sensus pertanian di negara berkembang yang dikarenakan keterbatasan anggaran. Responden (petani) diminta untuk memperkirakan produktivitas, produksi dan luas tanaman dalam wawancara (FAO, 2018).

Dengan penerapan skenario antisipasi pada masa Covid-19, pemasukan data (response rate) komoditas padi hanya mencapai $65,10 \%$. Realisasi tertinggi yaitu pulau sulawesi sebesar $73,79 \%$ dan realisasi terendah yaitu pulau Maluku-Papua sebesar 44,44\%. Perbandingan target dan realisasi menurut pulau dapat dilihat pada Gambar 1.

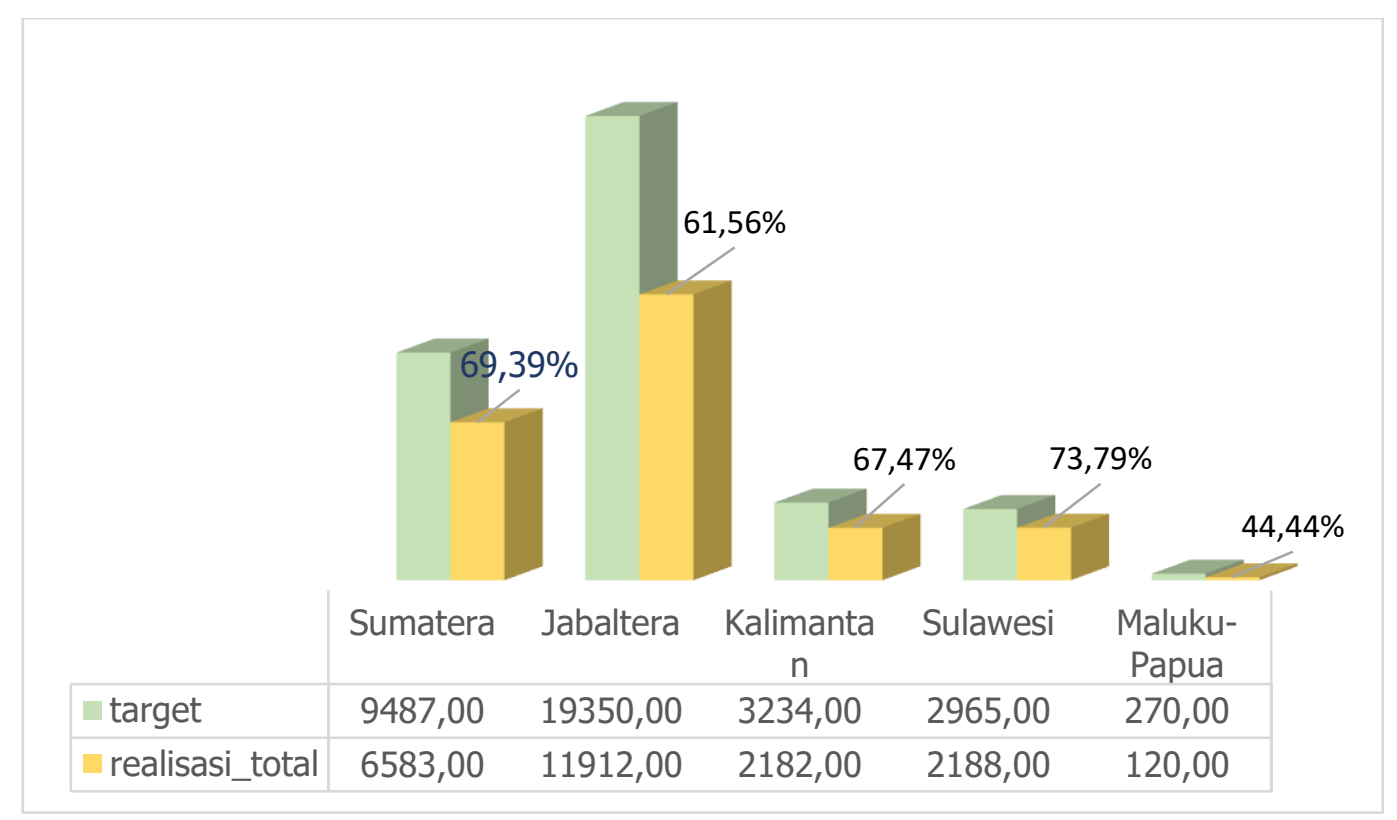

Gambar 1. Perbandingan target dan realisasi menurut pulau.

Berdasarkan metode pelaksanaannya, 70,49\% petugas tetap menggunakan metode pengukuran dan wawancara sedangkan sisanya sekitar $29,51 \%$ petugas menggunakan metode wawancara tanpa pengukuran. Metode pengukuran dan wawancara paling banyak dilakukan di pulau Sumatera sebesar $79,64 \%$ dan metode wawancara tanpa pengukuran paling banyak dilakukan di pulau Sulawesi sebesar 43,97\%. 


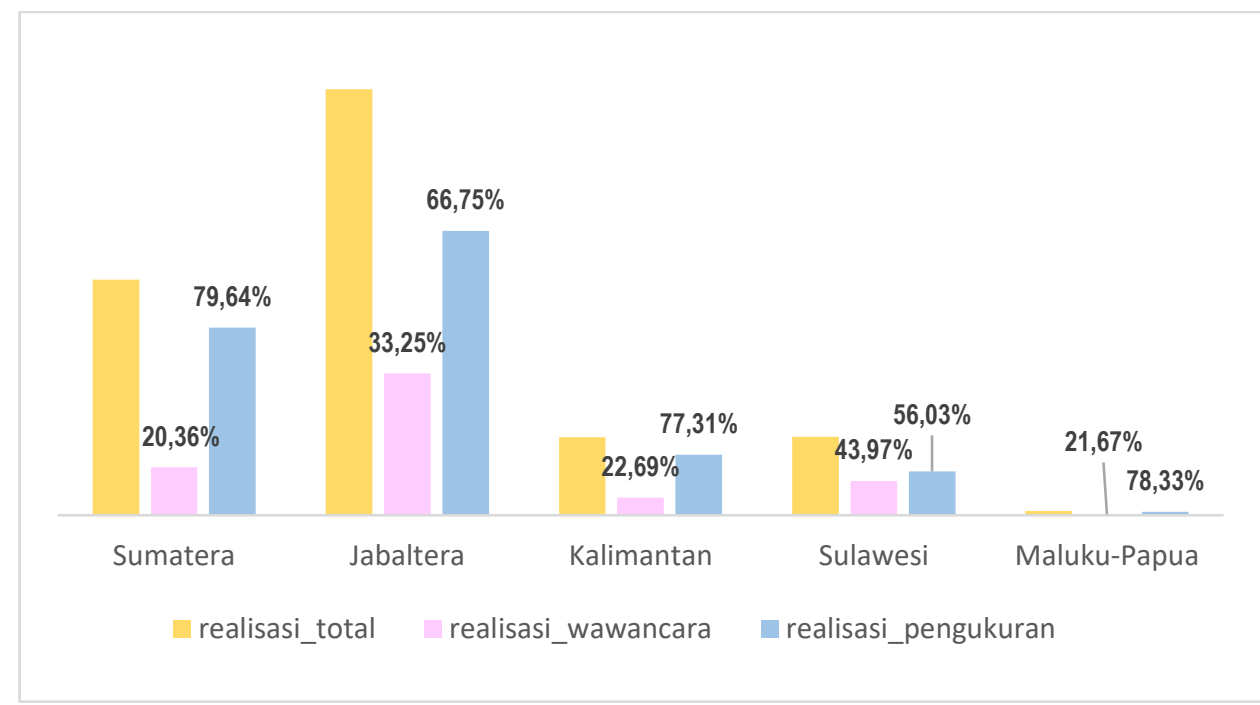

Gambar 2. Realisasi berdasarkan metode pelaksanaan menurut pulau.

Rata-rata produktivitas padi Subround 12020 lebih kecil dibandingkan dengan rata-rata produktivitas padi Subround 1 2019, namun perbedaannya tidak terlalu signifikan. Dilihat dari pengelompokan pulau, Maluku-papua menunjukkan perbedaan yang paling besar yaitu 0,32 ton/ha, sementara itu hanya sulawesi yang menunjukkan rata-rata produktivitas subround 12020 (4,76 ton/ha) lebih besar dibandingkan subround 12019 (4,61 ton/ha).

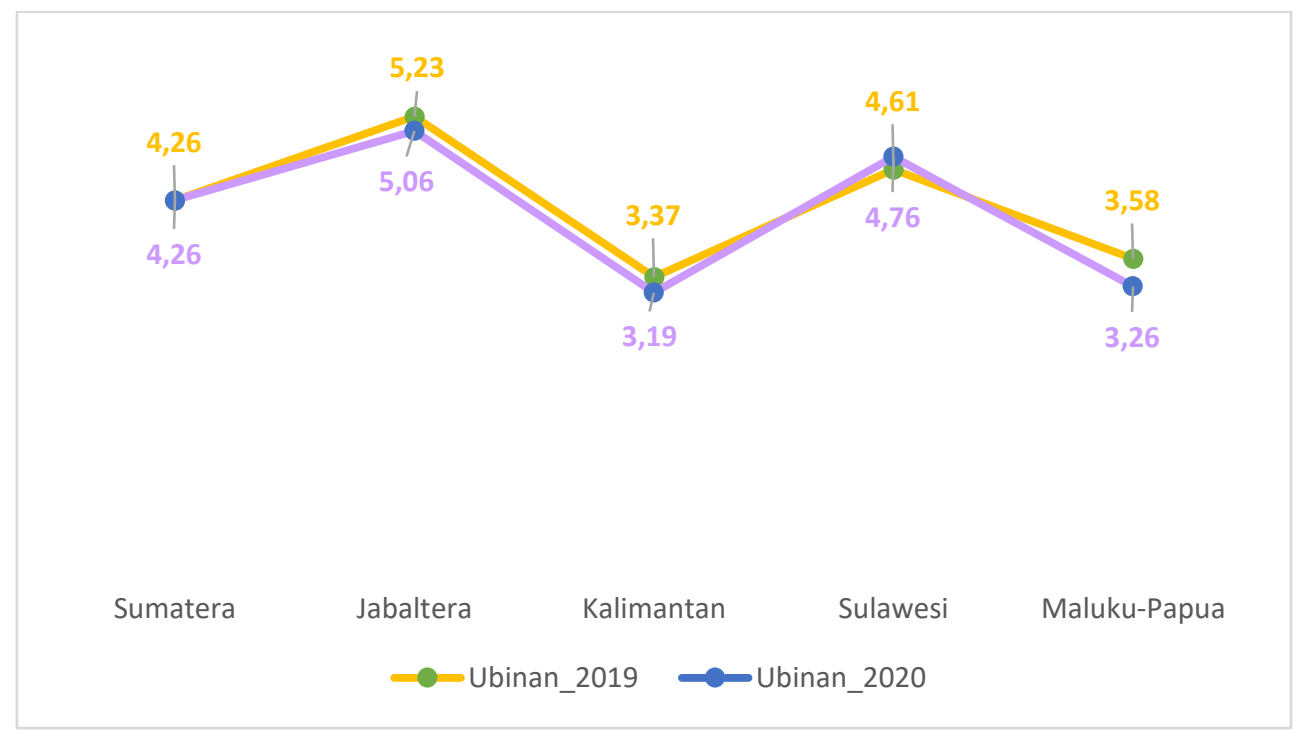

Gambar 3. Rata-rata produktivitas padi subround 12019 dan subround 12020 menurut pulau

Analisis lebih lanjut dilakukan dengan menerapkan uji T-Test menggunakan data Subround 1 2020 yang menunjukkan bahwa tidak ada perbedaan yang signifikan rata-rata produktivitas pengukuran dengan wawancara dan wawancara tanpa pengukuran dengan $t$ tabel $(0,05 ; 4)=$ 2,776445 .

Tabel 2. Hasil Pengujian Paired Samples T-Test

\begin{tabular}{|c|c|c|c|c|c|c|c|c|c|}
\hline \multicolumn{10}{|c|}{ Paired Samples Test } \\
\hline & & \multicolumn{5}{|c|}{ Paired Differences } & \multirow[b]{3}{*}{$\mathrm{t}$} & \multirow[b]{3}{*}{ df } & \multirow{3}{*}{$\begin{array}{l}\text { Sig. (2- } \\
\text { tailed) }\end{array}$} \\
\hline & & \multirow[b]{2}{*}{ Mean } & \multirow{2}{*}{$\begin{array}{c}\text { Std. } \\
\text { Deviation }\end{array}$} & \multirow{2}{*}{$\begin{array}{l}\text { Std. Error } \\
\text { Mean }\end{array}$} & \multicolumn{2}{|c|}{$\begin{array}{c}95 \% \text { Confidence } \\
\text { Interval of the } \\
\text { Difference }\end{array}$} & & & \\
\hline & & & & & Lower & Upper & & & \\
\hline Pair 1 & $\begin{array}{l}\text { Wawancara } \\
\text { - } \\
\text { Pengukuran }\end{array}$ & $-0,31000$ & 0,34460 & 0,15411 & $-0,73788$ & 0,11788 & $-2,012$ & 4 & 0,115 \\
\hline
\end{tabular}




\section{KESIMPULAN}

Pada masa pandemi Covid-19, data produktivitas tanaman pangan tetap dapat diperoleh dengan melakukan modifikasi pada tata cara pendataan, pemilihan sampel, dan pengolahan. Meskipun sudah diupayakan dengan cara demikian, tetap saja tidak dapat diperoleh informasi seoptimal kondisi normal. Realisasi data ubinan di masa pandemi Covid-19 masih rendah, metode pendataan dengan pengukuran dan wawancara tetap menjadi pilihan utama yang dilakukan pada sebagian besar daerah. Metode wawancara tanpa pengukuran tetap bisa menjadi alternatif karena tidak ada perbedaan yang cukup signifikan antara produktivitas padi metode pengukuran dan wawancara dengan metode wawancara tanpa pengukuran. Pada masa yang akan datang, metode wawancara tanpa pengukuran bisa menjadi alternatif yang bisa dipertimbangkan untuk menekan jumlahnya non response pada survei ubinan khususnya yang terlewat panen. Namun diperlukan penelitian lebih lanjut untuk mengikutsertakan variabel-variabel lain dan bisa juga dibandingkan antara hasil dari kuesioner lengkap (SUB-S) dan kuesioner sederhana (SUB-SW).

\section{DAFTAR PUSTAKA}

Bidarbakhtnia, A., Statistics, E., Reviewers, D., Halderen, G. Van, Division, E. S., Tam, S., Methodologist, C., Bureau, A., Yazdani, A., Escap, S., \& Division, S. (2020). Surveys Under Lockdown; a pandemic lesson. 23.

BPS. (2015). Pedoman Pengumpulan Data Survei Ubinan Tanaman Pangan 2015.

FAO. (2018). Handbook on crop statistics: improving methods for measuring crop area, production and yield. Global Strategy to Improve Agricultural and Rural Statistics, 204.

FAO. (2020). Novel Coronavirus (COVID-19) FAO launches the new COVID-19 Response. http://www.fao.org/2019-ncov/en/

Hermanto, Hadiutomo, K., Damanik, R. S., Rohmani, S. A., Marwoso, \& Simbolon, D. S. (2020). Dampak Covid-19 terhadap Sektor Pertanian. In Buletin Perencanaan Pembangunan Pertanian. https://doi.org/10.1017/CBO9781107415324.004

Hidayat, I., Wijayanto, H., \& Afendi, F. M. (2018). Evaluation of Paddy Production Mesurement in Indonesia. IOP Conference Series: Earth and Environmental Science. https://doi.org/10.1088/1755$1315 / 187 / 1 / 012035$

Lind, Douglas A., Marchal, William G., Wathen, S. A. (2012). Statistical Techniques in Business \& Economics.

Mahardika, M. N., Trisiana, A., Widyastuti, A., Juhaena, J. S., Mea, R., \& Kirani, A. (2020). Menumbuhkan Kesadaran Masyarakat Indonesia Untuk Memutus Rantai Penyebaran Wabah Covid-19. 1.

Menpan RB. (2020). SURAT EDARAN MENPAN NOMOR 19 TAHUN 2020. https://jdih.menpan.go.id/puu-994Surat Edaran Menpan.html

Sekretariat Kabinet RI. (2020). Sekretariat Kabinet Republik Indonesia_ Dua Rapat Terbatas Melalui Konferensi Video, Selasa 21 April 2020 - Sekretariat Kabinet Republik Indonesia.

https://setkab.go.id/gallery/dua-rapat-terbatas-melalui-konferensi-video-selasa-21-april-2020/ 